\title{
Differences in the genotype frequencies of genes related to blood pressure regulation - a comparative study between South-West Europe and Peri-equatorial Africa
}

\author{
Laura Aguiar ${ }^{1,2,3}$, Ildegário Semente ${ }^{1,2,4}$, Joana Ferreira ${ }^{1,2,3}$, Andreia Carvalho ${ }^{1,2,3}$, Alda P Silva ${ }^{1,2,3}$, \\ Cristina Caroça ${ }^{5,6}$, Helena Caria ${ }^{7,8}$, Albertino Damasceno, ${ }^{9,10}$, Maria J Laires ${ }^{3}$, Luís Sardinha ${ }^{11}$, \\ Cristina Monteiro $^{11}$, Mário R Mascarenhas ${ }^{3,12}$, Paula Faustino ${ }^{3,4}$, *Ângela Inácio ${ }^{1,2,3}$, Manuel Bicho ${ }^{1,2,3}$
}

1. Instituto de Investigação Científica Bento da Rocha Cabral, Lisboa, Portugal.

2. Laboratório de Genética, Faculdade de Medicina da Universidade de Lisboa, Lisboa, Portugal.

3. Instituto de Saúde Ambiental, Faculdade de Medicina da Universidade de Lisboa, Lisboa, Portugal.

4. Departamento de Genética Humana, Instituto Nacional de Saúde Doutor Ricardo Jorge, Lisboa, Portugal.

5. Departamento de Otorrinolaringologia, Faculdade de Ciências Médicas, Universidade Nova de Lisboa, Portugal.

6. Hospital CUF Infante Santo, Lisboa, Portugal.

7. BioISI - Biosystems \& Integrative Sciences Institute, Faculty of Sciences, University of Lisbon, Portugal.

8. Departamento de Ciências Biomédicas, Escola Superior de Saúde, Instituto Politécnico de Setúbal, Setúbal.

9. Faculdade de Medicina da Universidade Eduardo Mondlane, Maputo, Moçambique.

10. Hospital Central de Maputo, Maputo, Moçambique.

11. Centro de Estudos da Performance Humana, Faculdade de Motricidade Humana da Universidade de Lisboa, Lisboa, Portugal.

12. Clínica de Endocrinologia, Diabetes e Metabolismo de Lisboa, Lisboa, Portugal.

\begin{abstract}
Background: Since the emergence of the genus Homo, hominids have occupied a wide variety of environments, facing different selective pressures.

Objectives: The aim this study is to compare genotype frequencies between South-West Europe and Peri-equatorial Africa in genes potentially modulators of blood pressure.

Methods: The analyzed sample consisted of 325 individuals from Portugal and 226 individuals from Africa (48 from Mozambique and 178 from São Tomé and Príncipe). The following genetic variants were analyzed: intron 4 VNTR in eNOS, rs1050829 in G6PD, -3.7kb $\alpha$-thalassemic deletion in HBA, rs1800457 in CYB5R3, Hp 1/2 genotype/phenotype in Hp and intron $16 \mathrm{I} / \mathrm{D}$ in ACE.

Results: Frequencies of genotypes with the 4a allele in eNOS $(p<0.001)$, the G allele in G6PD ( $p<0.001)$, the $\alpha-3.7 \mathrm{~kb}$ in HBA ( $p<0.001)$, the $C$ allele in the CYB5R3 $(p<0.001)$ were higher in Peri-equatorial Africa. The Hp 1.1 genotype of Hp has a higher frequency in Peri-equatorial Africa $(\mathrm{p}=0.002)$. ACE shows no significant differences.

Conclusion: Results show differences in five genetic variants. Conditions of extreme heat and humidity, characteristic of Peri-equatorial Africa, have been associated with increased sodium loss. This study suggests that selected compensatory mechanisms printed in the genome, are nowadays risk factors for hypertension in Peri-equatorial Africa.
\end{abstract}

Keywords: Blood pressure, genetics, Africa.

DOI: https:// dx.doi.org/10.4314/abs.v21 i4.21

Cite as: Aguiar L, Semente I, Ferreira J, Carvalho A, Silva AP, Carosa C, et al. Differences in the genotype frequencies of genes related to blood pressure regulation-a comparative study between South-West Europe and Peri-equatorial Africa. Afri Health Sci. 2021;21(4):1669-76. bttps:/ / dx.doi.org/10.4314/abs.v21i4.21

\section{Corresponding author:}

Angela Inácio,

Instituto de Investigação Científica Bento da Rocha Cabral, Lisboa, Portugal Complete address: Calçada Bento da Rocha Cabral, 14, Lisboa, Portugal E-mail: minacio@medicina.ulisboa.pt

\section{Introduction}

Blood pressure is controlled by complex mechanisms not yet completely clarified. However, it is well accepted that maintenance of normal blood pressure depends on the interaction between genes and environment and that genetic variability may play an important role in the pathological process of hypertension ${ }^{1,2}$. In fact, in recent years several genes have been associated with 
blood pressure control and susceptibility to hyperten$\operatorname{sion}^{3-6}$.

Nitric oxide (NO) is synthesized from L-arginine by endothelial nitric oxide synthase (eNOS) and plays an important role in several physiological processes. It is a potent vasodilator agent allowing the maintenance of vascular tonicity and blood pressure regulation ${ }^{7-9}$.

Another enzyme that plays an important role in the pathophysiology of hypertension is glucose-6-phosphate dehydrogenase (G6PD). This enzyme generates nicotinamide adenine dinucleotide phosphate (NA$\mathrm{DPH})$, a co-factor for NO synthesis, and its deficiency is associated with decreased $\mathrm{NO}^{10}$. Several studies have found an association between G6PD enzyme deficiency and hypertension or/and cardiovascular disease ${ }^{11-13}$.

Endothelial alpha-globin $(\mathrm{Hb} \alpha)$ and cytochrome b5 reductase 3 (Cyb5R3) may also regulate NO bioavailability. An interaction mechanism has been described between $\mathrm{Hb} \alpha$ and eNOS, both forming a macromolecular complex in the myoendothelial junctions, important for $\mathrm{NO}$ signaling between endothelium and smooth muscle ${ }^{14}$. Moreover, NO diffusion from endothelium towards smooth muscle is regulated by the oxidative state of the $\mathrm{Hb} \alpha$ heme group, with NO having a high affinity to iron in its reduced form ${ }^{15-18}$. Cyb5R3 is a methemoglobin reductase that controls the oxidative state of the $\mathrm{Hb}$ $\alpha$ heme group by reducing $\mathrm{Fe} 3+$ to $\mathrm{Fe} 2+{ }^{17}$.

One of the most studied markers of sodium susceptibility to blood pressure over the past years is haptoglobin ( $\mathrm{Hp}$ ). Hp is an acute phase plasma glycoprotein characterized by an inter-individual molecular variation, its main function is to bind free hemoglobin ( $\mathrm{Hb})$,forming a complex that will be eliminated by monocytes and hepatocytes ${ }^{19}$. As part of the free $\mathrm{Hb}$ elimination mechanism, $\mathrm{Hp}$ will act as an antioxidant, protecting against free radicals ${ }^{20}$. There are three distinct genotypes / phenotypes (Hp 1.1, Hp 2.1 and $\mathrm{Hp} 2.2$ ) that bind to $\mathrm{Hb}$ with different affinities ${ }^{21}$.

Angiotensin converting enzyme I (ACE) is an enzyme that plays a key role in blood pressure control by catalyzing the conversion of angiotensin I to angiotensin II, a potent vasoconstrictor and a aldosterone production enhancer that increases sodium retention ${ }^{22,23}$, thus deviations on its regular function may be implicated in pathogenesis of high blood pressure.
Following the emergence of the genus Homo, hominids occupied a wide variety of environments with different temperatures and humidity, as a result, selective pressures are expected to vary between geographically distinct regions ${ }^{24,25}$. Several studies report an increased susceptibility to hypertension in populations ancestry from peri-equatorial environments, in association with an adaptive cardiovascular regulation of salt loss by perspiration $^{26-28}$.

The aim of the present work is to compare genotype frequencies in genes potentially modulators of blood pressure, in South-West Europe and Peri-equatorial Africa. Genes are endothelial nitric oxide synthase (eNOS), glucose-6-phosphate dehydrogenase (G6PD), alpha globin (HBA), cytochrome b5 reductase 3 (CYB5R3), haptoglobin ( $\mathrm{Hp}$ ) and angiotensin converting enzyme I (ACE).

\section{Methods}

Subjects: In this work we studied a group of 325 individuals from South-West Europe (Portugal), and 226 from Peri-equatorial Africa (48 from Mozambique plus 178 from São Tomé and Principe). The study protocol was approved by the local Ethical Committee. Written informed consent was obtained from all participants and the study was conducted in line with the principles of the Declaration of Helsinki. Because, sometimes we could not obtain high quality data and it was not possible to repeat sample collection, there is a different $\mathrm{N}$ number per gene.

Genomic DNA Isolation: Whole blood samples from patients and controls were stored with EDTA at $-20^{\circ} \mathrm{C}$. The genomic DNA was isolated through a nonenzymatic method adapted from Lahiri and Numberger (1991)29.

eNOS Genotyping: Analysis of the variable number tandem repeats (VNTR $27 \mathrm{bp}-4 \mathrm{a} / \mathrm{b}$ ) in intron 4 of the eNOS gene, was made by PCR screening. PCR was carried out in a $25 \mu \mathrm{L}$ reaction volume, containing $\approx 200 \mathrm{ng}$ of genomic DNA, $1 \mu \mathrm{L}$ ( $20 \mathrm{pmol})$ of each of sense and antisense primers: 5'AGGCCCTATGGTAGTGCCTTT3' and 5'TCTCTTAGTGCTGTGGTCAC3'. These primers amplify a fragment with $293 \mathrm{bp}$ (4a) or $420 \mathrm{bp}$ (4b). The PCR program included a step of $94{ }^{\circ} \mathrm{C}$, for 5 min followed by 30 cycles of denaturation at $94{ }^{\circ} \mathrm{C}$ for $30 \mathrm{~s}$, annealing at $55^{\circ} \mathrm{C}$ for $45 \mathrm{~s}$ and extension at $72{ }^{\circ} \mathrm{C}$ for $30 \mathrm{~s}$. An additional extension step was performed in the final at $72{ }^{\circ} \mathrm{C}$ for $5 \mathrm{~min}$. PCR products were sepa- 
rated on 3\% agarose gel with ethidium bromate staining and visualized under UV light.

G6PD Genotyping: The rs1050829 of the G6PD gene was characterized by PCR followed by Restriction Fragment Length Polymorphism (RFLP). PCR was carried out in a $25 \mu \mathrm{L}$ reaction volume, containing $\approx 200$ ng of genomic DNA, $1 \mu \mathrm{L}(20 \mathrm{pmol})$ of each of sense and antisense primers: 5'CTGCGT'T'TCTCCGCCAATC3' and 5'AGGCAACGGCAAGCCTTAC3'. These primers amplify a fragment with $585 \mathrm{bp}$. The PCR program included a step of $94{ }^{\circ} \mathrm{C}$, for $5 \mathrm{~min}$ followed by 30 cycles of denaturation at $94{ }^{\circ} \mathrm{C}$ for $30 \mathrm{~s}$, annealing at $62,8^{\circ} \mathrm{C}$ for $30 \mathrm{~s}$ and extension at $72{ }^{\circ} \mathrm{C}$ for $30 \mathrm{~s}$. An additional extension step was performed in the final at $72{ }^{\circ} \mathrm{C}$ for $5 \mathrm{~min}$. PCR products were separated on $2 \%$ agarose gels with ethidium bromate staining and visualized under UV light. The amplified fragment was then restricted by Fok I (enzyme from New England Biolabs, Germany) originating fragments of 402 bp plus 187 bp (higher G6PD activity) or 289 bp, 187 bp plus 117 bp (lower G6PD activity). The results were visualized in a $1 \%$ agarose gel ethidium bromate stained and visualized under UV light.

$\alpha$-globin Genotyping: For the $\alpha-3,7 \mathrm{~kb}$ thalassemic deletion, a Gap-PCR was performed. PCR was carried out in $25 \mu \mathrm{L}$ reaction volume, containing $\approx 200$ ng of genomic DNA, $1 \mu \mathrm{L}(20 \mathrm{pmol})$ of sense primers (5'GGGATGCACCCACTGGCACT3') plus $1 \mu \mathrm{L}$ (20 pmol) of each antisense primer (5'CTCCAT'TGTTGGCACAT'TCCGGG3' and 'CTGCTGTCCACGCCCATGCC3'). These primers amplify a fragment with $2100 \mathrm{bp}$ (no deletion) or $1900 \mathrm{bp}$ (deletion). The PCR program included a step of $94^{\circ} \mathrm{C}$, for 5 min followed by 30 cycles of denaturation at $94{ }^{\circ} \mathrm{C}$ for $60 \mathrm{~s}$, annealing at $64{ }^{\circ} \mathrm{C}$ for $60 \mathrm{~s}$ and extension at $72{ }^{\circ} \mathrm{C}$ for $150 \mathrm{~s}$. An additional extension step was performed in the final at $72{ }^{\circ} \mathrm{C}$ for $5 \mathrm{~min}$. PCR products were separated on $1 \%$ agarose gel with ethidium bromate staining and visualized under UV light.

CYB5R3 Genotyping: For the rs1800457 characterization on CYB5R3 gene, a PCR end Point analysis was performed using a MyGo Proß Real time PCR detection System. The sequences of the labeled probe were CCCTCCAGCGGGAAACTTGGGATGG[C/G] TGTCCTTGAAGTAAACCTGCAAGAC (VIC/ FAM) (Assay ID C 2986212_20, Thermo Fisher Scientific, Portugal). Thermal cycling conditions consisted of an initial denaturation step at $95^{\circ} \mathrm{C}$ for $10 \mathrm{~min}, 40$ cycles of $95{ }^{\circ} \mathrm{C}$ for $15 \mathrm{~s}$, and $60{ }^{\circ} \mathrm{C}$ for $60 \mathrm{~s}$. PCR data were analyzed using MyGo Pro PCR Software 3.4.

Haptoglobin Genotyping: The Hp genotype was determined by polyacrylamide gel electrophoresis (PAGE). A 10\% hemoglobin solution in water was prepared from heparinized blood by first washing the blood cells five times in phosphatebuffered saline $(0.1$ $\mathrm{mol} / \mathrm{L}, \mathrm{pH}$ 7.2) and then lysing the cells in $9 \mathrm{~mL}$ of sterile water per milliliter of pellet cell volume. A supernatant of a cell lysate containing hemoglobin was aliquoted in 1 or $0.5 \mathrm{~mL}$ and stored at -20C. Hp phenotyping was determined by gel electrophoresis and peroxidase staining, using a modified version of the method described previously30. Briefly, serum (20mL) was mixed with $10 \mathrm{~mL}$ of the $10 \%$ hemoglobin solution and $15 \mathrm{~mL}$ of $40 \%$ saccharose, and the samples were left to stand for 5 minutes at room temperature to allow the formation of $\mathrm{Hp}-\mathrm{Hb}$ complexes. The $\mathrm{Hp}$ $\mathrm{Hb}$ complex was resolved by PAGE using a buffer containing $50 \mathrm{mmol} / \mathrm{L}$ Tris base and $384 \mathrm{mmol} / \mathrm{L}$ glycine. The gel was $14 \mathrm{~mL}$ of $40 \%$ acrylamide/bis-acrylamide in $14 \mathrm{~mL}$ of $3 \mathrm{~mol} / / \mathrm{L}$ Tris-HCl, $\mathrm{pH} 8.9$ and $21 \mathrm{~mL}$ of bidestilated water. Three hundred and fifty microliters of N,N,N',N'-Tetramethylethylenediamine and $1 \mathrm{~mL}$ of ammonium persulphate $(12 \mathrm{mg} / \mathrm{mL})$ were added to the previous solution. After the completion of electrophoresis, which was performed at a constant voltage of 250 for 4 hours, the $\mathrm{Hp}-\mathrm{Hb}$ complexes were visualized by soaking the gel in two freshly prepared staining solutions in a glass tray. The first staining solution contained ortho-dianisidine $5 \mathrm{mg} / \mathrm{mL}$ in $50 \%$ (vol/vol) glacial acetic acid, and the second one was made of $2 \%$ (vol/ vol) hydrogen peroxide. The bands corresponding to the $\mathrm{Hp}-\mathrm{Hb}$ complex were readily visible within 15 minutes and were stable for more than 48 hours.

ACE Genotyping: The analysis of the I/D (insertion/ deletion) on the ACE gene was screening in DNA samples by a PCR approach. PCR was carried out in a 25 $\mu \mathrm{L}$ reaction volume, containing $\approx 200 \mathrm{ng}$ of genomic DNA, $1 \mu \mathrm{L}(20 \mathrm{pmol})$ of each of sense and antisense primers: 5'GCCCTGCAGGTGTCTGCAGCATGT3' and 5'GGATGGCTCTCCCCGCCTTCTCTC3'. These primers amplify a fragment with $319 \mathrm{bp}$ (D) or $597 \mathrm{bp}(\mathrm{I})$. The PCR program included a step of $94^{\circ} \mathrm{C}$, for $5 \mathrm{~min}$ followed by 30 cycles of denaturation at 94 ${ }^{\circ} \mathrm{C}$ for $60 \mathrm{~s}$, annealing at $58{ }^{\circ} \mathrm{C}$ for $60 \mathrm{~s}$ and extension at $72{ }^{\circ} \mathrm{C}$ for $60 \mathrm{~s}$. An additional extension step was per- 
formed in the final at $72{ }^{\circ} \mathrm{C}$ for $5 \mathrm{~min}$. PCR products were separated on $2 \%$ agarose gel with ethidium bromate staining and visualized under UV light.

Statistical analysis: All tests were performed with SPSS 24.0 software. Differences between the two groups (South-West Europe and Peri-equatorial Africa) were tested with Pearson's chi-squared test or Fisher's Exact test when more than $20 \%$ of the data had less than 5 counts. Statistical significance was defined as a p-value $<0.05$.

\section{Results}

Comparison of the genotype frequencies between Peri-equatorial Africa and South-West Europe in eNOS, G6PD, HBA, CYB5R3, Hp and ACE genes is shown in Table 1. It is possible to observe that, apart from ACE gene, after clustering some genotypes, distributions are different between the two geographical localizations. Regarding eNOS, genotypes with the $4 \mathrm{a}$ allele $(4 \mathrm{a} / 4 \mathrm{a}$ and $4 \mathrm{a} / 4 \mathrm{~b})$ have a higher frequency in Peri-equatorial Africa (64,6 \%) than in South-West Europe (32,5 $\%)(p<0,001)$. For G6PD, there is a higher frequency of genotypes with the $G$ allele ( $G, G G$ and $A G)$ in Peri-equatorial Africa $(45,7 \%)$ than in South-West Europe $(2,1 \%)(\mathrm{p}<0,001)$. The presence of the $\alpha-3,7 \mathrm{~kb}$ deletion in the HBA gene $(\alpha-3,7 / \alpha-3,7$ and $\alpha \alpha / \alpha-3,7)$ is common in Africa (72,7 \%) but rare in South-West Europe $(1,2 \%)(p<0,001)$. Concerning CYB5R3, there is a higher frequency of genotypes carrying the $\mathrm{C}$ allele (CC and GC) in Peri-equatorial Africa (50,0\%) than in South-West Europe $(5,9 \%)(\mathrm{p}<0,001)$. In relation to $\mathrm{HP}$, there is a higher frequency of genotypes Hp 1.1 in Peri-equatorial Africa (37,5\%) once compared with South-West Europe $(16,8 \%)(p=0,002)$. ACE shows no significant differences in genotype distribution between the two geographical regions.

Table 1 - Comparison of genotype frequencies between Peri-equatorial Africa and South-West Europe - eNOS, G6PD, HBA, CYB5R3, Hp and ACE genes

\begin{tabular}{|c|c|c|c|c|}
\hline $\begin{array}{c}\text { Gene } \\
\text { (variant) }\end{array}$ & Genotype & $\begin{array}{c}\text { Peri- } \\
\text { equatorial } \\
\text { Africa N (\%) }\end{array}$ & $\begin{array}{l}\text { South-West } \\
\text { Europe N (\%) }\end{array}$ & $P$ value \\
\hline \multirow{2}{*}{$\begin{array}{c}\text { eNOS } \\
\text { (VNTR intron 4) }\end{array}$} & $4 a / 4 a$ and $4 a / 4 b$ & $51(64,6)$ & $51(32,5)$ & \multirow{2}{*}{$<0,001^{1}$} \\
\hline & $4 b / 4 b$ & $28(35,4)$ & $106(67,5)$ & \\
\hline \multirow{2}{*}{$\begin{array}{c}G 6 P D \\
\text { (rs1050829) }\end{array}$} & G, GG and $A G$ & $91(45,7)$ & $3(2,1)$ & \multirow{2}{*}{$<0,001^{1}$} \\
\hline & $A$ and $A A$ & $108(54,3)$ & $137(97,9)$ & \\
\hline \multirow{2}{*}{$\begin{array}{c}H B A \\
(\alpha / \alpha-3,7 \mathrm{~kb}) \\
\end{array}$} & $\alpha-3,7 / \alpha-3,7$ and $\alpha \alpha / \alpha-3,7$ & $16(72,7)$ & $1(1,2)$ & \multirow{2}{*}{$<0,001^{2}$} \\
\hline & $\alpha \alpha / \alpha \alpha$ & $6(27,3)$ & $81(98,8)$ & \\
\hline \multirow{2}{*}{$\begin{array}{c}\text { CYB5R3 } \\
\text { (rs1800457) }\end{array}$} & $\mathrm{CC}$ and $\mathrm{GC}$ & $59(50,0)$ & $3(5,9)$ & \multirow{2}{*}{$<0,001^{1}$} \\
\hline & GG & $59(50,0)$ & $48(94,1)$ & \\
\hline \multirow{2}{*}{$\begin{array}{c}H p \\
\text { (protein phenotype } \\
2.2 / 2.1 / 1.1 \text { ) } \\
\end{array}$} & 2.2 and 2.1 & $30(62,5)$ & $154(83,2)$ & \multirow[b]{2}{*}{$0,002^{1}$} \\
\hline & 1.1 & $18(37,5)$ & $31(16,8)$ & \\
\hline$A C E$ & DD and ID & $39(92,9)$ & $213(89,5)$ & \multirow[b]{2}{*}{$0,503^{2}$} \\
\hline (Insertion/Deletion) & ॥ & $3(7,1)$ & $25(10,5)$ & \\
\hline
\end{tabular}

\section{Discussion}

The epidemics of hypertension is certainly related with nowadays environmental risk factors, such as excessive salt consumption or eating behaviors leading to obesity. However, also genetic susceptibility contributes to this disease onset. Different populations present differ- ent susceptibilities, with populations originated from hot and humid environments, being more susceptible than populations from cold environments ${ }^{26-28}$. This is probably due, not only to cultural (consanguinity) and infectious factors ${ }^{31}$ (positive selection in G6PD and HBA by malaria), but also to a historic adaptation of 
the human being to climate ${ }^{27}$. Indeed, factors that nowadays increase susceptibility to hypertension, such as vascular reactivity and sodium and water retention, may have been adaptive in an ancestral African environment characterized by a hot, humid and salt-poor climate ${ }^{28,32}$.

In this study there are significant differences in eNOS genotype frequencies between the two groups, with the smaller allele ( $4 \mathrm{a}$ - four VNTR of $27 \mathrm{bp})$ in intron 4 (a/b) being more frequent in Africa. This result is in accordance with the literature, that reports differences between African and European populations ${ }^{33}$. The $4 \mathrm{a}$ allele is associated with a lower gene expression leading to a reduction in the $\mathrm{NO}$ levels and consequently to a loss of endothelium integrity ${ }^{34}$. In fact, some studies found an association between the $4 \mathrm{a}$ allele and the susceptibility to hypertension and cardiovascular risk ${ }^{35-38}$.

Concerning rs1050829 in the G6PD, in accordance with other reported results ${ }^{39}$, there is a higher frequency of the $G$ containing genotypes in Africa. This variant is associated with lower levels of the enzyme $e^{40,41}$, providing lower amounts of NADPH to act as cofactors for the NO production and potentially leading to vascular disfunction and hypertension.

Regarding HBA gene, it was found an association of the $-\alpha 3,7 \mathrm{~Kb}$ variant with Africa. Other studies show the same ${ }^{42-44}$. This deletion may disturb the $\mathrm{Hb} \alpha /$ eNOS interaction and compromise the macromolecular complex stability in myoendothelial joints, interfering with the regular NO signaling between endothelium and smooth muscle. Likewise, for the CYB5R3 gene, results are in accordance with other studies, showing the $\mathrm{C}$ containing allele being more frequent in Africa ${ }^{45}$. Results obtained from our group revealed an association between rs1800457 and a higher activity of the enzyme in Sickle Cell Disease patients (not published). Other authors showed an association between high Cyb5R3 levels and hypertension ${ }^{46}$.

In accordance with previous studies, we also detected a higher frequency of the Hp 1.1 genotype in Africa ${ }^{47}$. Other authors have associated the Hp 2.2 genotype with susceptibility of blood pressure to sodium ${ }^{46,48-50}$. One possible explanation is the lower protection that Hp 2 provides against vascular complications, since it binds with a lower affinity to Hemoglobin ${ }^{51}$. On the other hand, Hp 1 is a potent inhibitor of PGE2 biosynthesis, a natriuretic product ${ }^{52}$. Schaer et al. demonstrated that Hemoglobin binding by $\mathrm{Hp}$ restores vascular
NO signaling during hemolysis ${ }^{53}$ consequently, for the higher frequency of the Hp 1.1 genotype in Africa may also contributed a selection of the Hp 1 allele in a context of highly frequent hemolytic diseases.

Several studies have demonstrated an association between hypertension and ACE gene. One of the most studied polymorphism in this gene is the I/D, characterized by an insertion/deletion of $287 \mathrm{bp}$ in intron ${ }^{6}$, being the $\mathrm{D}$ allele associated with physiologic alterations that can lead to hypertension development ${ }^{54,55}$. Previous studies that compared the I/D distribution between Caucasians and sub-Saharan Africans descendants, show a higher frequency of the $\mathrm{D}$ allele in the second ones $^{56,57}$. However, our results, in agreement with Sagnella et al. do not find significant differences between South-West Europe and Peri-equatorial Africa ${ }^{58}$.

Effective heat dissipation is essential in hot environments and is most efficiently achieved through perspiration, which can lead to loss of large amounts of salt and water ${ }^{59}$. Under these conditions, salt desire and renal sodium conservation are essentials for survival therefore, in the past, humans and nonhuman primates from tropical climates increased their salt avidity ${ }^{60-63}$. Perspiration also causes a drop in blood volume ${ }^{64}$, under these conditions, compensatory mechanisms involved in increasing arterial tone and cardiac contraction force, maintain regular blood pressure values. Thus, genetic variation that increases arterial and cardiac contractility may have conferred survival advantage in the environmental context of early human evolution in Peri-equatorial Africa. Today, after civilization, Africans are less exposed to extreme environmental conditions, highlighting the adaptive compensatory mechanisms acquired over time by selection, in the form of hypertension. However, other selective pressures such as malaria (positive selection for G6PD polymorphism and $\alpha-3.7 \mathrm{~kb}$ ) and cultural habits such as inbreeding, surely also contributed for the selection of risk genotypes for hypertension.

\section{Conclusion}

In the present study we found differences in the genotypic distributions of five genetic variants between two distinct geographic regions - South-West Europe and Peri-equatorial Africa, that are involved in the cardiovascular regulation and potentially influence the development of hypertension. To this contrast may have contributed, different selective pressures associated with the distinct climates. In fact, conditions of extreme heat and humidity are associated with increased sodium loss, 
which is relevant to blood pressure maintenance. Thus, this study suggests that initially selected compensatory mechanisms that become printed in the genome, are now risk factors for the development of hypertension.

\section{Acknowledgments}

The authors are grateful to all study participants and would like to thank the Instituto de Investigação Científica Bento da Rocha Cabral for financial support.

\section{References}

1. Fan W, Qu X, Li J, Wang X, Bai Y, Cao Q, et al. Associations between polymorphisms of the ADIPOQ gene and hypertension risk: A systematic and meta-analysis. Sci Rep. 2017;7:1-11 PubMed.

2. Poulter NR, Dorairaj P, Caulfield M. Hypertension. Lancet. 2015;386:801-12 PubMed.

3. Polonia JJ, Martins L, Pinto F, Nazare J, Bicho M. Association of 10 genes polymorphisms with essential hypertension risk among a representative sample of adult population of portugal (PHYSA study). J Am Soc Hypertens. 2015;9:e74.

4. Harrison M, Maresso K, Broeckel U. Genetic determinants of hypertension: an update. Curr Hypertens Rep. 2008; 10:488.

5. Russo A, Di Gaetano C, Cugliari G, Matullo G. Advances in the genetics of hypertension: the effect of rare variants. Int J Mol Sci. 2018;19:688.

6. Iwai N, Tago N, Yasui N, Kokubo Y, Inamoto N, Tomoike $\mathrm{H}$, et al. Genetic analysis of 22 candidate genes for hypertension in the Japanese population. J Hypertens. 2004;22:1119-26 PubMed.

7. Dias-Junior CA, Cau SB de A, Tanus-Santos JE. Role of nitric oxide in the control of the pulmonary circulation: physiological, pathophysiological, and therapeutic implications. J Bras Pneumol. 2008;34:412-9 PubMed.

8. Serrano NC, Díaz LA, Casas JP, Hingorani AD, Moreno-De-Luca D, Páez MC. Frequency of eNOS polymorphisms in the Colombian general population. BMC Genet. 2010;11:54.

9. Gewaltig MT, Kojda G. Vasoprotection by nitric oxide: mechanisms and therapeutic potential. Cardiovasc Res. 2002;55:250-60 PubMed.

10. Gaskin RS, Estwick D, Peddi R. G6PD deficiency: its role in the high prevalence of hypertension and diabetes mellitus. Ethn Dis. 2001;11:749-54 PubMed.

11. Zhao J, Zhang X, Guan T, Wang X, Zhang H, Zeng $\mathrm{X}$, et al. The association between glucose-6-phosphate dehydrogenase deficiency and abnormal blood pressure among prepregnant reproductive-age Chinese females. Hypertens Res. 2019;42:75.

12. Hecker PA, Leopold JA, Gupte SA, Recchia FA,
Stanley WC. Impact of Glucose 6-Phosphate Dehydrogenase Deficiency on the Pathophysiology of Cardiovascular Disease. Am J Physiol Circ Physiol. 2012; 304:H491-500.

13. Kurdyukov S, Eccles CA, Desai AA, Gonzalez-Garay M, Yuan JX-J, Garcia JGN, et al. New cases of glucose-6-phosphate dehydrogenase deficiency in pulmonary arterial hypertension. PLoS One. 2018;13:e0203493. 14. Straub AC, Butcher JT, Billaud M, Mutchler SM, Artamonov M V, Nguyen AT, et al. Hemoglobin $\alpha /$ eNOS coupling at myoendothelial junctions is required for nitric oxide scavenging during vasoconstriction. $A r$ terioscler Thromb Vasc Biol. 2014;34:2594-600 PubMed.

15. Helms C, Kim-Shapiro DB. Hemoglobin-mediated nitric oxide signaling. Free Radic Biol Med. 2013;61:46472 PubMed.

16. Butcher JT, Johnson T, Beers J, Columbus L, Isakson BE. Hemoglobin $\alpha$ in the blood vessel wall. Free Radic Biol Med. 2014;73:136-42 PubMed.

17. Straub AC, Lohman AW, Billaud M, Johnstone SR, Dwyer ST, Lee MY, et al. Endothelial cell expression of haemoglobin $\alpha$ regulates nitric oxide signalling. Nature. 2012;491:473-7 PubMed.

18. Reddy PL, Bowie LJ, Callistein S. Binding of nitric oxide to thiols and hemes in hemoglobin H: implications for $\alpha$-thalassemia and hypertension. Clin Chem. 1997;43:1442-7 PubMed.

19. Wobeto VP de A, Zaccariotto TR, Sonati M de F. Polymorphism of human haptoglobin and its clinical importance. Genet Mol Biol. 2008;31:602-20 PubMed.

20. Barbosa LCP, Miranda-Vilela AL, de Oliveira Hiragi $\mathrm{C}$, Ribeiro IF, Daldegan $\mathrm{MB}$, Grisolia $\mathrm{CK}$, et al. Haptoglobin and myeloperoxidase (- G463A) gene polymorphisms in Brazilian sickle cell patients with and without secondary iron overload. Blood Cells, Mol Dis. 2014;52:95-107 PubMed.

21. Dzudzor B, Nuwormegbe S, Asmah RH, Sodzi-Tettey NA, Kudzi W, Brown C. Haptoglobin Genotypes And Longevity Among The Ghanaian Population. Int J Sci Tecnol Res. 2014;3:18-22 PubMed.

22. Bae Y, Park C, Han J, Hong YJ, Song HH, Shin ES, et al. Interaction between GNB3 C825T and ACE I/D polymorphisms in essential hypertension in Koreans. $J$ Hum Hypertens. 2007;21:159-66 PubMed.

23. Matsubara M, Suzuki M, Fujiwara T, Kikuya M, Metoki H, Michimata M, et al. Angiotensin-converting enzyme I/D polymorphism and hypertension: the Ohasama study. J Hypertens. 2002;20:1121-6 PubMed.

24. Hancock AM, Witonsky DB, Alkorta-Aranburu G, Beall CM, Gebremedhin A, Sukernik R, et al. Adaptations to climate-mediated selective pressures in $\mathrm{Hu}-$ mans. Plos Genet. 2011;7:e1001375. 
25. Katzmarzyk PT, Leonard WR. Climatic Influences on Human Body Size and Proportions: Ecological Adaptations and Secular Trends. Am J Phys Anthropol. 1998;106:483-503 PubMed.

26. Burt VL, Whelton P, Roccella EJ, Brown C, Cutler JA, Higgins M, et al. Prevalence of hypertension in the US adult population: results from the Third National Health and Nutrition Examination Survey, 1988-1991. Hypertension. 1995;25:305-13 PubMed.

27. Young JH, Chang Y-PC, Kim JD-O, Chretien J-P, Klag MJ, Levine MA, et al. Differential susceptibility to hypertension is due to selection during the out-of-Africa expansion. PLoS Genet. 2005;1:e82.

28. Moskowitz DW. Hypertension, thermotolerance, and the "African gene": an hypothesis. Clin Exp Hypertens. 1996;18:1-19 PubMed.

29. Lahiri DK, Nurnberger Jr JI. A rapid non-enzymatic method for the preparation of HMW DNA from blood for RFLP studies. Nucleic Acids Res. 1991;19:5444. 30. Linke RP. Typing and subtyping of haptoglobin from native serum using disc gel electrophoresis in alkaline buffer: Application to routine screening. Anal Biochem. 1984;141:55-61 PubMed.

31. Williams TN, Weatherall DJ. World distribution, population genetics, and health burden of the hemoglobinopathies. Cold Spring Harb Perspect Med. 2012;2:a011692.

32. Gleiberman L. Salt, hypertension, evolution. Psychosom Med. 2001;63:325-7 PubMed.

33. Thomas BN, Thakur TJ, Yi L, Guindo A, Diallo DA, Ott J. Extensive ethnogenomic diversity of endothelial nitric oxide synthase (eNOS) polymorphisms. Gene Regul Syst Bio. 2013;7:GRSB-S10857.

34. Tsukada T, Yokoyama K, Arai T, Takemoto F, Hara S, Yamada A, et al. Evidence of association of the ecNOS gene polymorphism with plasma NO metabolite levels in humans. Biochem Biophys Res Commun. 1998;245:190-3.

35. Munshi A, Rajeshwar K, Kaul S, Chandana E, Shafi $\mathrm{G}$, Anila AN, et al. VNTR polymorphism in intron 4 of the eNOS gene and the risk of ischemic stroke in a South Indian population. Brain Res Bull. 2010;82:247-50 PubMed.

36. Nejatizadeh A, Kumar R, Stobdan T, Goyal AK, Sikdar S, Gupta M, et al. Endothelial nitric oxide synthase gene haplotypes and circulating nitric oxide levels significantly associate with risk of essential hypertension. Free Radic Biol Med. 2008;44:1912-8 PubMed.

37. Chen Q, Wang H, Xiao D, Liang T, Yu J, Yang J. Association between eNOS 4b/a polymorphism and susceptibility of pulmonary hypertension: a meta-anal- ysis of 6 studies. Int J Clin Exp Med. 2016;9:15510-7 PubMed.

38. Patkar S, Charita BH, Ramesh C, Padma T. High risk of essential hypertension in males with intron 4 VNTR polymorphism of eNOS gene. Indian J Hum Genet. 2009;15:49-53 PubMed.

39. https://www.ensembl.org/Homo_sapiens/Variation/Population?db=core;r=X:154534777-154535777 $; \mathrm{v}=\mathrm{rs} 1050829 ; \mathrm{vdb}=$ variation; $\mathrm{vf}=15841518$ (Accessed: 5.03.2019).

40. dos Santos SLF, da Silva Prado RM, Oliveira CPA, Pessoa CV, Borges RN, Barros KBNT. Associação da deficiência da glicose-6-fosfato desidrogenase (G6PD) em população brasileira afrodescendente. Bol Inf Geum. 2016;7:106.

41. Enevold A, Vestergaard LS, Lusingu J, Drakeley CJ, Lemnge MM, Theander TG, et al. Rapid screening for glucose-6-phosphate dehydrogenase deficiency and haemoglobin polymorphisms in Africa by a simple high-throughput SSOP-ELISA method. Malar J. 2005; $4: 61$.

42. Modell B, Darlison M. Global epidemiology of haemoglobin disorders and derived service indicators. Bull World Health Organ. 2008;86:480-7 PubMed.

43. Mockenhaupt FP, Ehrhardt S, Gellert S, Otchwemah RN, Dietz E, Anemana SD, et al. $\alpha+$-thalassemia protects African children from severe malaria. Blood. 2004;104:2003-6 PubMed.

44. Peres MJ, Carreiro MH, Machado MC, Seixas T, Picanço I, Batalha L, et al. Rastreio neonatal de hemoglobinopatias numa população residente em Portugal. Acta Med Port. 1996;135-9.

45. https://www.ensembl.org/Homo_sapiens/Variation/Explore? $\mathrm{r}=22: 42627765-42628765 ; \mathrm{v}=\mathrm{rs} 1800457$ $; \mathrm{vdb}=$ variation; $\mathrm{vf}=64406904$ (Accessed: 13.03.2019).

46. Monteiro C, Lança M, Joaquim N, Lamy I, Aníbal J, Coucelo J, et al. Polimorfismo genético da haptoglobina e grau de gravidade da hipertensão arterial essencial. Rev Port Cardiol. 1997;16:81-4 PubMed.

47. Carter K, Worwood M. Haptoglobin: a review of the major allele frequencies worldwide and their association with diseases. Int J Lab Hematol. 2007;29:92-110 PubMed.

48. Prabha S, Padma T, Ramaswamy M. Haptoglobin patterns in essential hypertension and associated conditions-increased risk for Hp 2-2. Hum Hered. 1987; 37:345-8 PubMed.

49. Delanghe JR, Duprez DA, De Buyzere ML, Bergez BM, Callens BY, Leroux-Roels GG, et al. Haptoglobin polymorphism and complications in established essential arterial hypertension. J Hypertens. 1993;11:861-7. 
50. Delanghe JR, Duprez DA, De Buyzere ML, Bergez BM, Claeys LR, Leroux-Roels GG, et al. Refractory hypertension is associated with the haptoglobin 2-2 phenotype. J Cardiovasc Risk. 1995;2:131-6 PubMed.

51. Langlois MR, Delanghe JR. Biological and clinical significance of haptoglobin polymorphism in humans. Clin Chem. 1996;42:1589-600 PubMed.

52. Saeed SA, Ahmad N, Ahmed S. Dual inhibition of cyclooxygenase and lipoxygenase by human haptoglobin: its polymorphism and relation to hemoglobin binding. Biochem Biophys Res Commun. 2007;353:915-20 PubMed.

53. Schaer CA, Deuel JW, Schildknecht D, Mahmoudi L, Garcia-Rubio I, Owczarek C, et al. Haptoglobin preserves vascular nitric oxide signaling during hemolysis. Am J Respir Crit Care Med. 2016;193:1111-22.

54. Rana G, Yadav S, Joshi S, Saraswathy KN. Association of DD genotype of angiotensin-converting enzyme gene (I/D) polymorphism with hypertension among a North Indian population. J Community Genet. 2018;9:51-5 PubMed.

55. Abraham WT, Raynolds M V, Badesch DB, Wynne KM, Groves BM, Roden RL, et al. Angiotensin-converting enzyme DD genotype in patients with primary pulmonary hypertension: increased frequency and association with preserved haemodynamics. J Renin-Angiotensin-Aldosterone Syst. 2003;4:27-30 PubMed.

56. Barley J, Blackwood A, Miller M, Markandu ND, Carter ND, Jeffery S, et al. Angiotensin converting enzyme gene I/D polymorphism, blood pressure and the renin-angiotensin system in Caucasian and Afro-Caribbean peoples. J Hum Hypertens. 1996;10:31-5 PubMed. 57. Crews DE, Cruickshank JK, Jeffery S. Angio- tensin converting enzyme insertion/deletion polymorphism: association with ethnic origin. $J$ Hypertens. 1994;12955:957.

58. Sagnella GA, Rothwell MJ, Onipinla AK, Wicks PD, Cook DG, Cappuccio FP. A population study of ethnic variations in the angiotensin-converting enzyme I/D polymorphism: relationships with gender, hypertension and impaired glucose metabolism. $J$ Hypertens. 1999;17:657-64 PubMed.

59. Newman RW. Why man is such a sweaty and thirsty naked animal: A speculative review. Hum Biol. 1970;1227.

60. Denton D, Weisinger R, Mundy NI, Wickings EJ, Dixson A, Moisson P, et al. The effect of increased salt intake on blood pressure of chimpanzees. Nat Med. 1995;1:1009.

61. Baker EH, Ireson NJ, Carney C, Markandu ND, MacGregor GA. Transepithelial sodium absorption is increased in people of African origin. Hypertension. 2001;38:76-80.

62. Vollmer WM, Sacks FM, Ard J, Appel LJ, Bray GA, Simons-Morton DG, et al. Effects of diet and sodium intake on blood pressure: subgroup analysis of the DASH-sodium trial. Ann Intern Med. 2001;135:1019-28 PubMed.

63. Brier ME, Luft FC. Sodium kinetics in white and black normotensive subjects: possible relevance to salt-sensitive hypertension. Am J Med Sci. 1994;307:S3842.

64. Sawka MN, Montain SJ, Latzka WA. Hydration effects on thermoregulation and performance in the heat. Comp Biochem Physiol Part A Mol Integr Physiol. 2001;128:679-90. 